\title{
THERMAL AND DEFORMATIVE CHARACTERISTICS OF KAOLIN RAW DEPOSITS OF THE REPUBLIC OF BELARUS
}

\author{
Olga A. SERGIEVICH ${ }^{\mathrm{a}}$, Eugenia M. DYATLOVA ${ }^{\mathrm{b}}$, Rostislav Yu. POPOV ${ }^{\mathrm{b}}$, \\ Alexander St. SOBACHEVSKII ${ }^{\mathrm{c}}$ \\ "The State Enterprise "Institute NIISM", 220014, Minsk, Minina str., 23, Belarus \\ ${ }^{b}$ Belorussian State Technological University, 220006, Minsk, Sverdlova str., 13a, Belarus \\ "JSC "Keramin", 220024, Minsk, Serova str., 22, Belarus
}

Received 24 august 2015; accepted 26 November 2015

\begin{abstract}
The article gives brief information about the most common kaolin raw deposits of the Republic of Belarus. Thermal and dilatometric characteristics of natural kaolins and kaolins enriched by clarification method of "Sitnitsa" and "Dedovka" deposits are studied in detail. It is found that these raw materials are industrially prospective in terms of its using in the production of silica-alumina refractories (semiacid and chamotte).
\end{abstract}

Keywords: kaolin, differential thermal analysis, dilatometric curve, shrinkage, enrichment, refractories.

\section{Introduction}

Kaolin deposits of the Republic of Belarus differ from traditional kaolin in their structure and properties because of the significant amount of mechanical impurities, increased content of coloring matter and other impurities (Sergievich et al. 2012). There are several kaolin deposits and occurrences on the territory of the Republic of Belarus, but the most common and studied are "Sitnitsa" and "Dedovka".

Reserves of primary raw kaolin of "Sitnitsa" deposit are counted in the amount of 2.53 million tons of $\mathrm{C}_{1}$ and $\mathrm{C}_{2}$ categories with the expected output of enriched kaolin $-30.5 \%$. The mineral is a gray clay rock, weakly chloritized with large inclusions of fragments mainly of feldspar-quartz composition, biotite, grains of quartz and feldspar. "Dedovka" deposit is represented by primary and secondary kaolins. It's a rock of yellowish-gray color with mechanical impurities of glauconite-quartz sand, muscovite, feldspar and fragments of crystalline rocks. Total reserves of primary raw kaolin are up to 7.02 million tons, the secondary -1.23 million tons with a yield of enriched kaolin $48.8 \%$ versus $28.4 \%$ in the primary (Khomich et al. 2002).

Nowadays, refractory industry uses refractory clay and kaolin: primary, secondary, carried by water currents for the production of chamotte refractory and semiacid aluminosilicate products. In the absence of the companies and lines producing refractory products in the Republic of Belarus nearly 16.5 tons of fireclay refractory materials totaling 6.4 million $\$$ per year are imported into the country annually and consumed, $30-50 \%$ of which could be obtained on the basis of local raw kaolins.

The results of the research of some structural features and properties of primary kaolin deposits of the Republic of Belarus are known (Levitsky et al. 1995; 2008). The prospect of their industrial use in natural and enriched form in some industries of ceramic production, including refractory, can be installed at the

Corresponding author:

O. A. Sergievich E-mail: topochka.83@mail.ru 
result of more deep and detailed study of characteristics properties of kaolins such as thermomechanical and deformation.

\section{Experimental part}

The average representative samples of primary kaolin "Sitnitsa" and "Dedovka" are used for research.

Phase transformations of the kaolin in the temperature range of $20-1200{ }^{\circ} \mathrm{C}$ were studied by differential thermal analysis, which was conducted by derivatograph DSC 404 F3 by the company NETZCH (Germany). Derivatograms of natural kaolins and kaolins, enriched by wet elutriation on the sieve number 0063 of deposits "Sitnitsa" and "Dedovka" are shown in Figure 1.

The presence of endothermic effect on DSC curves of kaolin "Sitnitsa" in natural form (Fig. 1a) at temperatures of $27-110^{\circ} \mathrm{C}$ and $110-145^{\circ} \mathrm{C}$ accompanied by removal of hygroscopic and adsorption water. A weight loss, corresponding to the first endothermic effect is $0.57 \%$, to the second $-0.13 \%$. Endothermic effect at temperatures near $150{ }^{\circ} \mathrm{C}$ on the curve of kaolinite is explained by presence of impurities of halloyasite which has a composition similar to kaolinite $\left(\mathrm{A}_{2} \mathrm{O}_{3} \cdot 2 \mathrm{SiO}_{2} \cdot 2 \mathrm{H}_{2} \mathrm{O}\right)$ (Brigatti et al. 2006). Intensive endothermic effect at temperatures $415-632{ }^{\circ} \mathrm{C}$, accompanied by weight loss of $4.81 \%$, corresponds to the destruction of the lattice of kaolinite upon cleavage and removing of crystallization water as the result of kaolinite decomposition according to reaction:

$$
\begin{gathered}
\mathrm{Al}_{2} \mathrm{O}_{3} \cdot 2 \mathrm{SiO}_{2} \cdot 2 \mathrm{H}_{2} \mathrm{O} \rightarrow\left[\mathrm{Al}_{2} \mathrm{O}_{3} \cdot 2 \mathrm{SiO}_{2}\right]+2 \mathrm{H}_{2} \mathrm{O} \\
\text { (Levitsky et al. 1999). }
\end{gathered}
$$

The metakaolinite $\left[\mathrm{Al}_{2} \mathrm{O}_{3} \cdot 2 \mathrm{SiO}_{2}\right]$ - is amorphous product with partial kaolinite structure. In this case, kaolinite, devoid of chemically bound water, irreversibly loses plasticity. The observed splitting of endothermic effects as a small step in the DSC curve at a temperature of $570-580^{\circ} \mathrm{C}$ is associated with transition of quartz from $\beta$ - to $\alpha$-form with the change in volume.

Exothermic effect in the temperature range of $978-1030{ }^{\circ} \mathrm{C}$ is associated with the processes of mullitization. In this case, there is dissociation of metakaolinite and subsequent merges of homogeneous structural units $\left[\mathrm{SiO}_{4}\right]$ and $\left[\mathrm{AlO}_{4}\right]$ in a more or less extended amorphous grouping of substances and the simultaneous growth of equivalence within the tetrahedral bonds. In parallel, sometimes a small amount of $\gamma-\mathrm{Al}_{2} \mathrm{O}_{3}$ or mullitolike phase is crystallized. There is no clear argument for exothermic effect at $950-980{ }^{\circ} \mathrm{C}$. It is most likely that the source of exothermict energy is a free energy of metakaolinite. Carbonates are dissociated with evolution of carbon dioxide, sulfides are oxidized to form sulfur dioxide and organic impurities are burn at temperature range of $700-1000{ }^{\circ} \mathrm{C}$. These processes are accompanied by a weight loss of $0.67 \%$, a slight increase in porosity and decrease in volume. General weight loss is about $6.20 \%$.

Metakaolinite rearranges to form of mullite at temperature of $1100{ }^{\circ} \mathrm{C}$ with heat release according to reaction:

$$
3\left[\mathrm{Al}_{2} \mathrm{O}_{3} \cdot 2 \mathrm{SiO}_{2}\right] \rightarrow 3 \mathrm{Al}_{2} \mathrm{O}_{3} \cdot 2 \mathrm{SiO}_{2}+4 \mathrm{SiO}_{2} \text {. }
$$

The amount of mullite continuously increases with increase of temperature, and reaches a maximum at a temperature of $1250-1350{ }^{\circ} \mathrm{C}$. Prolonged exposure at temperatures above $1200{ }^{\circ} \mathrm{C}$ does not affect to the increase in the yield of mullite, but it promotes the growth of crystals. Theoretically, all the alumina contained in kaolin, should go into mullite, however, a practical way of mullite never reaches the theoretical one (Castelein et al. 2001). Division of mullite in origin during firing of kaolinitcomprising masses into primary and secondary, as well as the selection of cubic intermediate phase (aluminumsilicate spinel) is given in the work (Pavlov, Mitrokhin 1979).

The nature of thermal effects of the raw kaolin of "Dedovka" deposit (Fig. 1b) - is similar to kaolin "Sitnitsa". The first endothermic effect in the temperature range of $27-110^{\circ} \mathrm{C}$ with a weight loss of $0.10 \%$ is characterized by a single minimum; the second endothermic effect is shifted right to $5-38{ }^{\circ} \mathrm{C}$ with a minimum at $\sim 530{ }^{\circ} \mathrm{C}$ with a weight loss of $2.84 \%$. Exothermic peak in the range of $960-1050{ }^{\circ} \mathrm{C}$ with a maximum at $988^{\circ} \mathrm{C}$ is characterized by a somewhat larger area due to more active mullitization of kaolinite. It is characterized by a weight loss of $0.27 \%$. The general weight loss is amounted to $3.21 \%$.

When "Sitnitsa" and "Dedovka" kaolins are heated in enriched form all endo- and exothermic effects are expressed more deeply, compared to the natural ones because of the absence of impurity minerals, i.e. their derivatograms are close to the curves of traditional kaolinite. Thus there is no splitting effect as a step on a DSC curve at a temperature of $570-580{ }^{\circ} \mathrm{C}$ (Fig. 1a, b) connected with polymorphic transformations of impurity quartz. The presence of more deeply expressed endothermic effect on the curves of the enriched kaolins in this temperature range is determined only by 

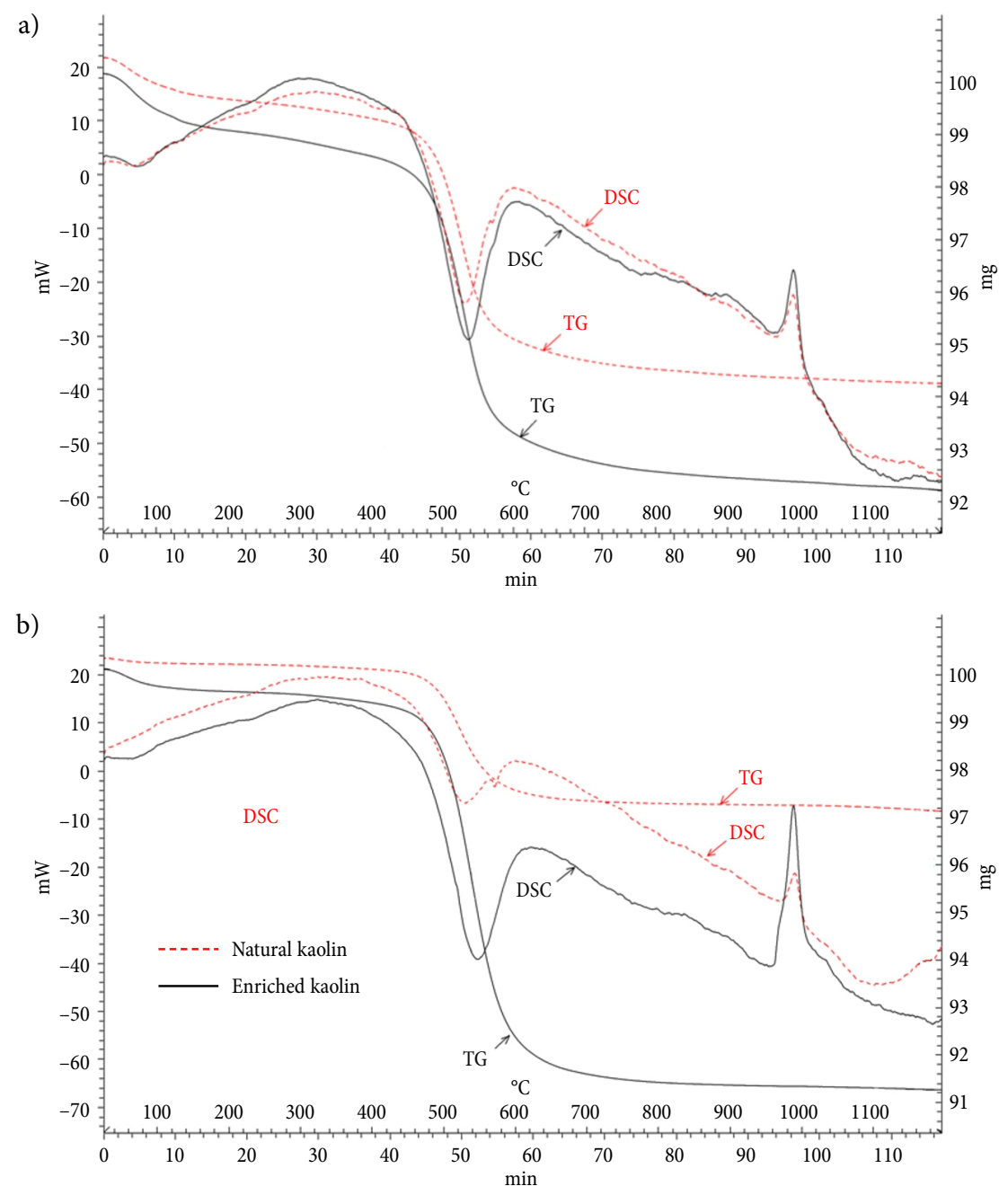

Fig. 1. Derivation of kaolin deposits "Sitnitsa" (a) and "Dedovka" (b)

the dehydration of the mineral and by the formation of the metakaolinite with the lattice ordered only in two directions. The exothermic effect undergoes a significant changes at temperature of $950-990{ }^{\circ} \mathrm{C}$ for enriched kaolins, which expands in this temperature range and is expressed by more intensely because of activation of the processes of restructuring prior to the formation of mullite (kaolinite mullitization) with decreasing volume.

It should be noted that if the Belarusian kaolin deposits contain impurities with temperatures of thermal effects, close enough to kaolinite, they are difficult to distinguish on the thermogram due to the high intensity of the thermal effects of the main mineral - kaolinite.

Figure 2 shows the high-temperature dilatometric curves of natural and enriched kaolin of "Sitnitsa" and "Dedovka" deposits in the temperature range of 100$1400^{\circ} \mathrm{C}$ at a heating rate of $50^{\circ} \mathrm{C} / \mathrm{min}$, obtained by optical heating microscope "MISURA ODHTHSM 1600-80".
There is little change in the size of both the samples of kaolin at temperatures up to $500{ }^{\circ} \mathrm{C}$, because their thermal expansion is largely compensated by shrinkage associated with the removal of the adsorbed water and the beginning of the dehydration of kaolinite. At a temperature of $500{ }^{\circ} \mathrm{C}$ expansion reaches its maximum value for the samples of enriched kaolin and goes into shrinkage which continues until the temperature of $735^{\circ} \mathrm{C}$ for kaolin "Sitnitsa" and is $1.18 \%$ and up to $700^{\circ} \mathrm{C}$ for kaolin "Dedovka" with shrinkage of $0.31 \%$ that is connected with removal of water of crystallization and the destruction of kaolinite lattice.

In this temperature range for both natural kaolin deposits is observed a slight expansion of the samples: $0.75 \%$ for kaolin "Sitnitsa" and $0.50 \%$ for kaolin "Dedovka". Probably it is connected with the polymorphic transformation of the impurity of quartz with an increase in volume. 

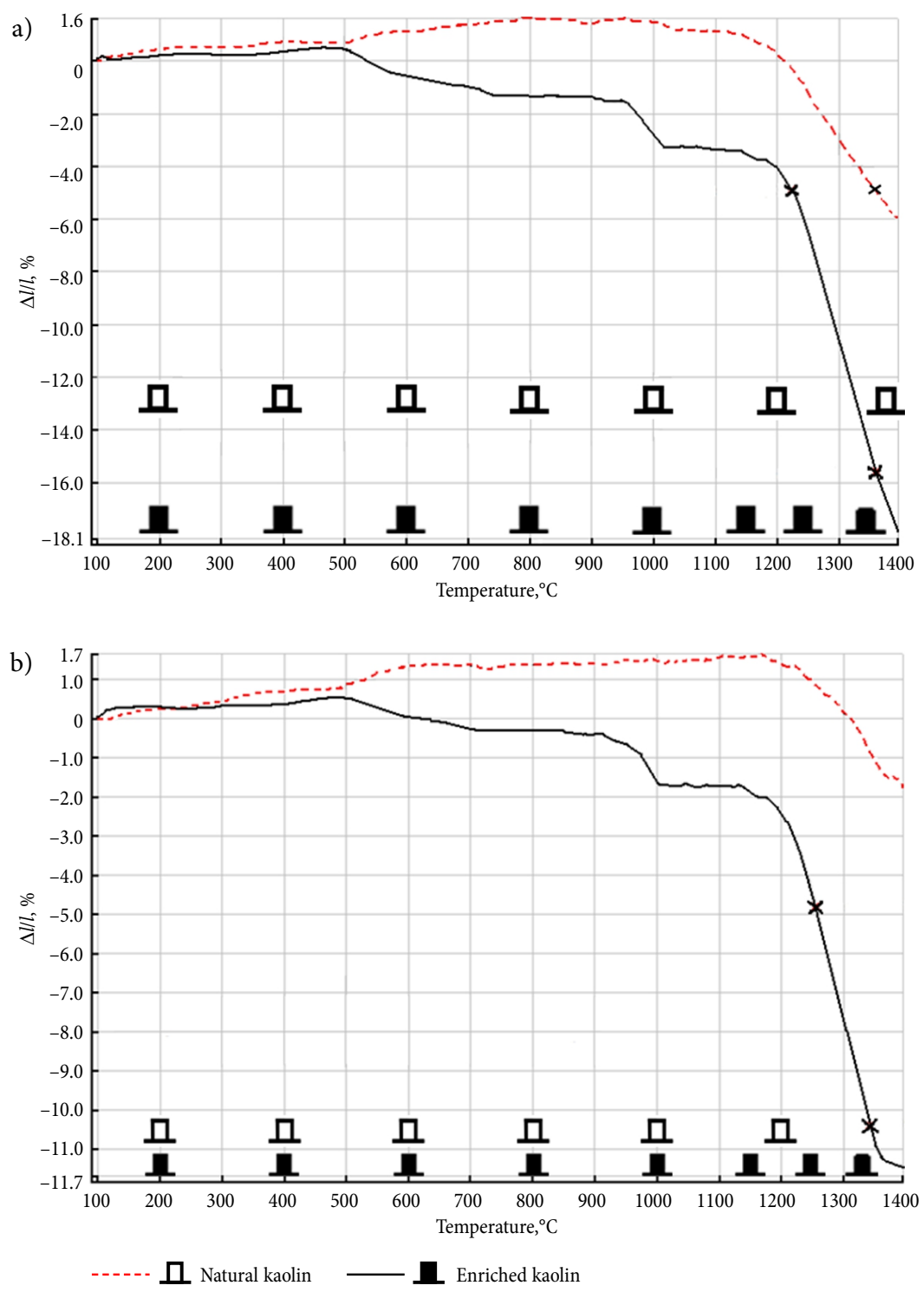

Fig. 2. The dilatometric curves of kaolin of "Sitnitsa" (a) and "Dedovka" (b) deposits

Futher, up to a temperature of $945^{\circ} \mathrm{C}$, the sample size is almost unchanged: shrinkage is compensated by thermal expansion. The sharp shrinkage in the temperature range of $950-1050^{\circ} \mathrm{C}$ for samples of enriched kaolin $(2.08 \%$ - "Sitnitsa" and $1.44 \%$ - "Dedovka") is determined by the dissociation of carbonate impurities, which present in small quantities, as well as beginning of the process of the mullite formation assists in sealing of structure.

Under these conditions unenriched kaolin samples, change their sizes with minor extension, which is likely determined by the formation of the modification phase of silica at $1060{ }^{\circ} \mathrm{C}$ - metastable $\alpha$-cristobalite, a sharp increase in the volume of which is somewhat offset by combining structural units of metakaolinite. Above the temperature of $1150{ }^{\circ} \mathrm{C}$ there is a sharp transition of dilatometric curves towards shrinkage, which indicates activation of the sintering process of kaolin both of deposits with the formation of mullite.

We should note the presence of the following thermal characteristic points on the dilatometric curve of enriched kaolin (the change of shape the sample in accordance with the procedure of study): 1) sintering, whereby sizing is set at $5 \%$ (the value of this temperature is $1225^{\circ} \mathrm{C}$ for "Sitnitsa" kaolin and $1257^{\circ} \mathrm{C}$ for "Dedovka" kaolin); 2) softening due to the liquid phase, which causes the rounding of corners and decrease of surface roughness, which corresponds to a temperature of $1362{ }^{\circ} \mathrm{C}$ for "Sitnitsa" kaolin with a total shrinkage of $15.70 \%$ and $1343{ }^{\circ} \mathrm{C}$ for "Dedovka" kaolin with a total shrinkage $10.45 \%$. 
Table 1. Chemical and technological parameters of raw kaolin

\begin{tabular}{|l|c|c|c|c|}
\hline \multirow{2}{*}{\multicolumn{1}{|c|}{ Indicator }} & \multicolumn{2}{c|}{ "Sitnitsa" kaolin } & \multicolumn{2}{c|}{ "Dedovka" kaolin } \\
\cline { 2 - 5 } & natural & enriched & natural & enriched \\
\hline Content of the defined component, \% ${ }^{*}:$ & & & & \\
$\mathrm{SiO}_{2}$ & 61.7 & 46.1 & 70.3 & 50.7 \\
$\mathrm{Al}_{2} \mathrm{O}_{3}+\mathrm{TiO}_{2}$ & 25.78 & 35.54 & 19.26 & 34.03 \\
$\mathrm{Fe}_{2} \mathrm{O}_{3}$ & 1.56 & 2.53 & 0.46 & 1.05 \\
\hline Content of fine fractions,\%: & & & & \\
$<0.01 \mathrm{~mm}$ & 27.6 & 81.4 & 17.0 & 55.1 \\
$<0.001 \mathrm{~mm}$ & 11.7 & 48.9 & 7.5 & 26.0 \\
\hline Refractoriness, ${ }^{\circ} \mathrm{C}$ & 1620 & 1710 & 1750 & 1780 \\
\hline
\end{tabular}

Notes: ${ }^{*}$ here and hereafter given weight content.

On the dilatometric curves of unenriched kaolin in the investigated temperature range temperature of the characteristic point of the sintering beginning is much higher: it is $1361{ }^{\circ} \mathrm{C}$ for natural "Sitnitsa" kaolin, and for "Dedovka" kaolin this point goes beyond the heating unit of measurement that indicates its higher fire resistance. Other characteristic points on the dilatometric curves of natural kaolin differences are not available, that is connected with their greater sanding, which prevents liquid phase sintering. Thus "Dedovka" kaolin has lower shrinkage values as compared with samples of "Sitnitsa" kaolin, that can also be explained by the presence of larger amounts of quartz impurities in the kaolin.

Table 1 summarizes the chemical and technological properties of the raw kaolin, characterized by the possibility of their use in the manufacture of refractory aluminosilicate as a main component of the mass.

It can be concluded that the content of $\mathrm{Al}_{2} \mathrm{O}_{3}$ in natural kaolin of the Republic of Belarus does not allow to use it for fireclay refractories (28-45\%); it is necessary to add components with high content of $\mathrm{Al}_{2} \mathrm{O}_{3}$. Initial raw materials requirements according to general classification criteria (standard technical documentation) are satisfied for kaolin in the enriched form.

\section{Conclusions}

Phase transformations during heating of natural kaolin of "Sitnitsa" and "Dedovka" deposits are almost identical. It should be noted that the presence of impurities is difficult to discern on the derivatograms due to the high intensity of thermoeffect of the main mineral kaolinite.

Kaolin of Belarus deposits as traditional kaolinite gives dilatometric curves that fix sharp shrinkage at temperatures of return of crystallization water and the beginning of kaolinite mullitization, which in turn can facilitate the selection of the firing (Lamberov et al. 2012).

It is established that in the production of aluminosilicate refractories both natural and enriched kaolin can be used, wherein the refractory industry has wide experience of mass production of such products obtained by dry pressing. By using unenriched kaolin raw materials low alumina semiacid aluminosilicate refractory materials can be obtained and on the basis of enriched kaolin - fireclay sealed aluminosilicate refractory materials in accordance with standard technical documentation.

High sanding of kaolin of the deposits of the Republic of Belarus allows using of feldspathic sands formed during their conditioning in the amount of $65-70 \%$, and the natural raw materials in the production of ceramic bricks with high thermomechanical characteristics used for masonry residential furnaces, heating units etc.

\section{References}

Brigatti, M. F.; Galan, E.; Theng, B. K. G. 2006. Structures and mineralogy of clay minerals. Chapter 2, in Developments in clay science, 19-86.

Castelein, O.; Soulestin, B.; Bonnet, J. P.; Blanchart, P. 2001. The influence of heating rate on the thermal behaviour and mullite formation from a kaolin raw material, Ceramics International 27(5): 517-522. http://dx.doi.org/10.1016/S0272-8842(00)00110-3

Khomich, P. Z., et al. (Eds.). 2002. Poleznoje iskopaemyje Belarusi. Minsk: Adukatssyya i vyhavanne. 528 p.

Lamberov, A. A.; Sitnikova, E. Yu.; Abdulganeeva, A. Sh. 2012. Kinetic features of phase transformation of kaolinite into metakaolinite for kaolin clays from different deposits, Russian Journal of Applied Chemistry 85(6): 892-897. http://dx.doi.org/10.1134/S1070427212060109

Levitsky, I. A., et al. 1995. Comprehensive study Belarusian kaolin as raw material for the ceramic industry, Glass and Ceramic 12: 17-21. 
Levitsky, I. A., et al. 1999. IR spectra and DTA curves of raw and silicate materials: textbook. Minsk: Belarusian State Technological University. $52 \mathrm{p}$.

Levitsky, I. A., et al. 2008. Kaolin Belarus and prospects for their use in the manufacture of materials of construction and industrial purpose, in Proceedings BSTU. Ser. III, Chemistry and Technology in inorganicin 16: 32-36.

Pavlov, V. F.; Mitrokhin, V. S. 1979. Formation of mullite during firing clays and its relation with properties of products, Proc. NIIstroykeramika 33: 30-52.

Sergievich, O. A., et al. 2012. Features of chemical and mineralogical composition and properties of kaolin deposits Belarusian, Glass and Ceramic 3: 25-31.

Olga A. SERGIEVICH is a graduate student of the department of glass and ceramic technologies. The Head of the ceramic materials and technologies for special purposes section of the State Enterprise "Institute NIISM". Research interests: comprehensive research of mineral raw materials; development of ceramic materials of construction and technical purposes on the basis of kaolin deposits of the Republic of Belarus.

Eugenia M. DYATLOVA, Candidate of Technical Sciences, Assistant Professor of the department of glass and ceramic technologies. Research interests: technical ceramics with a wide range of electrical characteristics; advanced technologies in the production of ceramic materials.

Rostislav Yu. POPOV, Candidate of Technical Sciences, Senior lecturer of the Department of glass and ceramic technologies. Research interests: development of heat-resistant ceramic materials and ceramics of building purposes.

Alexander St. SOBOCHEVSKII, Deputy Head of the Technology Officer-Chief Technology of the JSC “Keramin”. Research interests: development of ceramic compositions and glaze coatings for tiles of special purposes with high performance characteristics. 